\title{
STRATEGI EMPLOYEE RELATIONS MANAGEMENT DI PT. KEMFARM INDONESIA
}

\author{
Fathiya Nur Rahmi' ${ }^{1)}$, Hanny Hafiar ${ }^{2)}$, Priyo Subekti ${ }^{3)}$ \\ ${ }^{1)}$ Fakultas Ilmu Komunikasi, Universitas Padjadjaran \\ ${ }^{2)}$ Fakultas Ilmu Komunikasi, Universitas Padjadjaran \\ ${ }^{3)}$ Fakultas Ilmu Komunikasi, Universitas Padjadjaran \\ Email ;" fathiyanurrahmi@ gmail.com, ${ }^{2}$ ) hannyhafiar@gmail.com, ${ }^{3)}$ priyosubekti@gmail.com
}

\begin{abstract}
PT. Kemfarm Indonesia is a company engaged in the field of agribusiness knew that employee relationship becomes important thing for the progress of the company. This study aims to determine the process of employee relationship management in PT Kemfarm Indonesia. The method used is descriptive with qualitative data. The research data was collected by observation, structured interview and literature study. The results show that HRD PT Kemfarm Indonesia acts as an internal PR managed relationships between companies, from processes, organizing, monitoring, evaluation and development program. In the process of planning, organizing, and program evaluation, the communications channel has not been optimal. From the results of this study, the suggestions provided are companies that do mapping the situation specifically on the process of planning, organizing and evaluation by using an effective communication channel on every program implementation so that the main goal of the program can be achieved.
\end{abstract}

Keywords : Strategy, Management, Employee Relations

\section{PENDAHULUAN}

Perusahaan sebagai badan usaha dikelilingi oleh berbagai macam publik di sekitarnya. Salah satu publik internal perusahaan yang memilik peranan sangat penting adalah karyawan. Suatu perusahaan tidak mungkin tanpa karyawan, karena merekalah yang menggerakan atau menghidupkan perusahaan. Sehingga pengelolaan hubungan yang baik antara perusahaan dengan karyawan (Employee Relations) menjadi sebuah isu penting yang telah banyak disadari oleh perusahaan dalam lingkup global.

Oleh karena itu, dalam Jamali dan Mirshak (2007: 243-244), dikatakan bahwa: "The World Business Council for Sustainable Development (WBSCD) mendefinisikan CSR sebagai komitmen bisnis untuk berkontribusi pada pembangunan ekonomi berkelanjutan, bekerja bersama dengan para pekerja, keluarga mereka, dan komunitas lokal." (Rakhmawati \& Sani, 2016). Artinya, 
hubungan dengan karyawan bukan sekedar dapat dilakukan dalam kegiatan employee relations, karena dalam kegiatan CSR pun karyawan dapat dilibatkan sebagai pihak yang diberdayakan.

Selain itu, berdasarkan data yang dikutip dari Edelmen Trust Barometer (2011) menyatakan bahwa:

"Salah satu faktor yang membuat perusahaan terpercaya oleh publik adalah treats employess well atau memperlakukan karyawan dengan baik. Dengan skor $63 \%$, pemenuhan aspek memperlakukan karyawan dengan baik sangat penting untuk membangun reputasi perusahaan."

Kondisi ini membuktikan bahwa karyawan sudah disadari menjadi bagian penting dari perusahaan, tidak hanya untuk kepentingan bisnis dan kemajuan perusahaan tetapi juga untuk membangun kepercayaan stakeholers perusahaan, terutama klien. Fakta diatas hendaknya menjadi pengingat bagi perusahaan, terutama di Indonesia, untuk meningkatkan usaha dan perhatian mereka dalam aspek hubungan karyawan (Employee Relations).

Berdasarkan hasil pra penelitian ditemukan bahwa PT. Kemfarm Indonesia telah menyadari pentingnya membina employee relations dengan berupaya membangun komunikasi yang efektif antara perusahaan dengan karyawan melalui berbagai program yang diselenggarakan oleh HRD PT Kemfarm Indonesia yang menjalankan fungsi sebagai PR Internal perusahaan. Hal tersebut dijelaskan oleh Budianto selaku Manager HRD \& Communications PT Kemfarm Indonesia.

"Komunikasi menjadi suatu kebutuhan yang sangat mendasar pada seluruh aktivitas yang terjadi di perusahaan karena untuk mencapai tujuan bersama dari perusahaan. Sehingga komunikasi yang efektif kami jadikan dasar untuk menciptakan employee relations yang baik. Salah satu upaya kami adalah dengan membuat program-program yang dijalankan oleh HRD."

Hal ini sejalan dengan pemikiran bahwa "kemitraan antara organisasi bisnis dan komunitas baik internal maupun eksternal bertujuan untuk kemaslahatan bersama bukan sekedar mencari laba" (Nassaluka, Hafiar, \& Priyatna, 2016: 2234).

Adapun langkah-langkah strategis dalam mengelola Employee Relations menurut (Muhyi, dkk, 2016:123-124) adalah: "perencanaan, pengelolaan, pengawasan, evaluasi dan pengembangan." Kelima tahap tersebut sudah dilakukan oleh

\footnotetext{
${ }^{1}$ Wawancara Ke\#1 dengan Budianto selaku Manager HRD \& Communications PT Kemfarm Indonesia pada 20 Maret 2017 di Kantor Cabang Tanggerang
} 
PT Kemfarm Indonesia. Staff HRD PT Kemfarm Indonesia menjelaskan tujuan program Employee Relations adalah "menciptakan komunikasi yang efektif, meningkatkan produktivitas karyawan, dan membuat lingkungan kerja yang nyaman.”2

Proses perencanaan program dimulai dari pemetaan situasi. Pada proses awal perencanaan program, peran Departemen HRD sebagai pengelola program adalah menentukan saluran komunikasi yang dijadikan sumber data untuk merencanakan program.

Pada proses pengorganisasian hingga pengembangan program, Departemen HRD berperan sebagai penghubung antara pihak pimpinan perusahaan dengan karyawan. Hal ini bertujuan agar kebutuhan karyawan dapat terpenuhi dan sesuai dengan kondisi perusahaan sehingga dapat mencapai tujuan perusahaan. Tentu pada proses perencanaan hingga pelaksanaan program ditemukan berbagai kendala yang mempengaruhi tercapai atau tidaknya tujuan dilaksanakan program. Umumnya permasalahan terdapat pada pola komunikasi dan saluran komunikasi yang digunakan belum sesuai.

2 Wawancara Ke\#1 dengan Margareth Selaku Manager HRD PT Kemfarm Indonesia pada 06 Februari 2017 di Kantor Cabang Tanggerang
Pada prinsipnya, antara pimpinan dan karyawan harus memiliki sikap terbuka (open-mindedness), karena keterbukaan merupakan salah satu substansi dalam organisasi yang harus dilaksanakan (Suparna, Rahmawati, \& Winoto, 2013).

Penulis disini ingin meneliti dan menggali lebih dalam mengenai bagaimana Strategi Employee Relations Management di PT. Kemfarm Indonesia. Tujuan penelitian ini adalah untuk mengetahui bagaimana Strategi Employee Relations Management di PT. Kemfarm Indonesia yang terdiri atas lima tahapan yakni perencanaan, pengorganisasian, pengelolaan, pengawasan, evaluasi dan pengembangan agar kedepannya strategi yang dilaksanakan dapat berjalan degan efektif dan tujuan perusahaan bisa dipenuhi dengan baik, selain itu hal ini penting bagi kajian ilmu komunikasi dan Public Relations dalam Manajemen Public Relations.

\section{TINJAUAN PUSTAKA}

\section{a) Public Relations}

Public Relations, yang didefinisikan oleh (Jefkins, 2003:10) adalah :

"Semua bentuk komunikasi yang terencana, baik itu ke dalam maupun ke luar, antara suatu organisasi dengan semua khalayaknya dalam rangka mencapai 
tujuan-tujuan spesifik yang berlandaskan pada saling pengertian."

\section{b) Manajemen}

Manajemen berasal dari kala to manage yang artinya mengatur. Pengaturan dilakukan melalui proses dan diatur berdasarkan urutan dari fungsi-fungsi manajemen itu. Jadi, manajemen itu merupakan suatu proses untuk mewujudkan tujuan yang diinginkan. (Hasibuan, 2001: 2) menjelaskan tentang definisi manajemen yakni:

"Manajemen adalah ilmu dan seni yang mengatur proses pemanfaatan sumber daya manusia dan sumbersumber lainnya secara efektif dan efisien untuk mencapai tujuan."

\section{c) Employee Relations}

Employee atau karyawan adalah salah satu dari publik internal yang dijadikan sasaran dari program Public Relations. Tujuan Employee Relations adalah untuk menciptakan hubungan yang baik dalam tiap personal yang ada dalam satu perusahaan yang bersangkutan, guna menciptakan suasana kerja yang kondusif dan produktif. Karyawan (pekerja) dalam sebuah perusahaan atau instansi merupakan asset sangat penting. Employee Relations diharapkan menimbulkan hasil yang positif. (Ruslan, 2005:267) menjelaskan bahwa:
"Karyawan merasa dihargai dan diperhatikan oleh pihak pimpinan perusahaan, sehingga dapat menciptakan rasa memiliki (sense of belonging), motivasi, kreativitas dan ingin mencapai prestasi kerja semaksimal mungkin.”

\begin{tabular}{|c|c|c|}
\hline No & Aktivital & Indikatot \\
\hline 1. & ER Planning & $\begin{array}{l}\text { 1. Penyesuaian program ER dengan tujuan } \\
\text { 2. Perusahaan } \\
\text { 3. Penctaansituasi ER terhadap setiap unit } \\
\text { SDM }\end{array}$ \\
\hline 2. & ER Onganizing & $\begin{array}{l}\text { 1. Altivitas fungei pengelolaan FR } \\
\text { 2. Keberadasn leabaga pengelola ER }\end{array}$ \\
\hline 3. & ER Monitoring & $\begin{array}{l}\text { 1. Database perebaman (recond situasi ER) } \\
\text { 2. Pencatatan baras kasus dalain ER } \\
\text { 3. Penyelesaian permasabhan ER } \\
\text { terdokumentasikan }\end{array}$ \\
\hline 4. & ER Evaluating & $\begin{array}{l}\text { 1. Tinglat rutinitas evaluasi ER } \\
\text { 2. Proses evaluasi menghasillan alternative } \\
\text { perbaikas ER }\end{array}$ \\
\hline 5. & Developing ER. & $\begin{array}{l}\text { 1. Dukungan pernimpin dalam peningkatan } \\
\text { kaalitas ER } \\
\text { 2. Dilakukan inovani das kreativitas } \\
\text { perbaikan ER } \\
\text { 3. Tinglat kualitas ER. }\end{array}$ \\
\hline
\end{tabular}

Tabel 1 Employee Relations Assessment Basic Applications

Sumber : (Muhyi dkk, 2013: 131)

\section{d) Employee Relations Management}

Dalam penelitian sebelumnya yang dilakukan oleh (Mahavidyalaya, 2015: 5) dijelaskan definisi employee relations management adalah :

"ERM refers to managing the relation between the various employees in an organization. The relationship can be between employee and the employer as well as between employees at the same level; ERM is an art which effectively monitors and manages the relation between individuals either of the same team or from different teams. ERM activity helps in 
strengthening the union among the employees and ensures that each one is contented and enjoys a healthy relation with each other. ERM includes various activities undertaken by the superiors or the management to develop a healthy relation among the employees and extract the best out of each team member."

\section{e) Komunikasi efektif dalam meningkatkan kualitas Employee \\ Relations}

Komunikasi efektif merupakan solusi peningkatan kualitas hubungan kerja antar karyawan. Dalam suatu proses komunikasi selain media, pesan, dan feedback, ada dua actor yang berperan utama yaitu komunikator dan komunikan. Komunikator sebagai pemberi pesan dan komunikan sebagai penerima pesan. Dalam suatu hubungan kerja antarkaryawan, karyawan bisa menjadi komunikator dan komunikan secara bergantian. Menurut Ruslan dalam (Muhyi, 2016:134) komunikasi hubungan masyarakat internal dalam hal ini untuk membangun Employee relations dapat menjadi komunikasi yang efektif apabila:

“(1)Adanya keterbukaan manajemen perusahaan (open management system) terhadap karyawannya. (2) Saling menghormati atau menghargai (mutual appreciation) antara satu sama lain, baik bertindak sebagai pimpinan maupun sebagai bawahan demi tercapainya tujuan utama perusahaan. (3) Adanya kesadaran atau pengakuan dari pihak perusahaan akan nilai-nilai dari arti pentingnya suatu "komuniaksi timbal balik dengan para karyawannya.

Keberadaan seorang manager HRD / SDM dan Humas (Public Relations), yang tidak hanya memiliki keterampilan (skill) dan berpengalaman sebagai seorang komunikator, mediator dan hingga perusador."

Teori tersebut penting sekali dipakai guna mengetahui bagaimana jalannya komunikasi yang dilakukan supaya dalam penyampaian terhadap pihak internal (karyawan dapat berjalan dengan efektif.

\section{METODE PENELITIAN}

Metode yang digunakan dalam penelitian ini adalah deskriptif. Data-data pada penelitian ini berasal dari naskah wawancara, cacatan lapangan, foto, video tape, dokumen pribadi, catatan atau memo, dan dokumen resmi lainya. Pada penelitian ini, dalam pelaksanaanya meliputi data, 
analisis dan interpretasi tentang arti dan data yang diperoleh.

Menurut (Nazir, 2003: 54-55) tujuan dari penelitian deskriptif ini adalah:

“...untuk membuat deskripsi, gambaran, atau lukisan secara sistematis, factual dan akurat mengenai fakta-fakta, sifatsifat serta hubungan yang diselidiki. Kemudian perspektif waktu yang dijangkau dalam penelitian deskriptif adalah waktu sekarang, atau sekurangkurangnya jangka waktu yang masih terjangkau".

Penelitian ini menggunakan studi deskriptif karena peneliti ingin mengetahui proses yang sedang berlangsung yaitu proses pengelolaan strategi Employee Relations Management yang dilakukan PT Kemfarm Indonesia. Strategi ini masih berlangsung hingga sekarang dan sudah dilakukan secara berkelanjutan sehingga dalam perspektif waktu penelitian deskriptif masih berlaku dimana responden masih dalam jangkauan ingatannya.

Narasumber dalam penelitian ini adalah 1) Manager HRD; 2) Dua orang Staff HRD; 3) Manager HR \& Communication; 4) Manager Corporate Communication; 5)Manajer Produksi; 6)Staff Corporate Communication; 7) Staff Departemen Produksi; dan 8) Staff Quality Control PT Kemfarm Indonesia.
Teknik pengumpulan data yang digunakan dalam penelitian ini terdiri dari: 1) Wawancara mendalam (depth interview); 2)Observasi lapangan; dan 3) Dokumentasi. Analisis data dalam penelitian ini ialah analisis data induktif yaitu modelmodel, teori-teori, konsep, metode perbandingan tetap. Biasanya data dianalisis secara deskriptif yang sebagian besar dihasilkan dari wawancara dan catatan pengamatan, catatan dianalisis untuk memperoleh tema, dan pola-pola yang dideskripsikan dan diilustrasikan dengan contoh-contoh termasuk kutipan-kutipan.

Triangulasi yang digunakan peneliti adalah triangulasi sumber, hal ini bertujuan agar dapat menghilangkan perbedaanperbedaan konstruksi kenyataan yang ada dalam konteks suatu studi sewaktu mengumpulkan data tentang berbagai kejadian dan hubungan dari berbagai pandangan.

Menurut (Sugiono, 2012: 274). "Triangulasi dengan sumber dilakukan dengan cara mengecek data yang telah diperoleh melalui beberapa sumber." Dari beberapa sumber yang didapatkan data tersebut dideskripsikan, dikategorikan, mana pandangan yang sama, mana yang berbeda, dan mana yang spesifik dari beberapa 
sumber yang telah diwawancara. Data yang telah dianalisis oleh peneliti menghasilkan suatu kesimpulan selanjutnya dimintakan kesepakatan dengan sumber-sumber yang telah ditetapkan.

\section{HASIL DAN PEMBAHASAN}

\section{Hasil Penelitian}

Berikut hasil penelitian proses employee relations management di PT Kemfarm Indonesia yang dijelaskan berdasarkan elemen Employee Relations Assessment Basic Applications yang terdapat pada konsep Employee Relations Management dalam (Muhyi, dkk, 2013)

\section{1) Proses Perencanaan Employee Relations Management di PT Kemfarm Indonesia}

Proses perencanaan employee relations management dimulai dari penentuan tujuan program. Tujuan dari program yakni untuk mencipatakan sense of belonging pada karyawan, meningkatkan produktifitas kerja dan menciptakan komunikasi yang efektif antarkaryawan. Tujuan program Employee Relations disesuaikan dengan misi perusahaan yakni "Menciptakan kondisi terbaik bagi karyawan dalam bekerja untuk meningkatkan produktifitas".
Langkah yang kedua dalam proses perencanaan program Employee Relations adalah pemetaan situasi. Data yang digunakan dalam menyusun pemetaan situasi adalah survey akhir tahun karyawan. Saluran komunikasi yang digunakan sebagai sumber pemetaan situasi hanya survey akhir tahun yang bersifat satu arah. Tidak ada saluran komunikasi lain yang digunakan untuk pemetaan situasi agar sesuai perencanaan sesuai dengan kebutuhan karyawan.

Kemudian dalam proses perencanaan tidak ditemukan adanya ada proses komunikasi secara khusus yang melibatkan melibatkan seluruh departemen secara langsung untuk mengetahui kebutuhan karyawan.

Target dari strategi Employee Relations adalah seluruh karyawan PT Kemfarm Indonesia. Tidak ada segmentasi secara khusus untuk target dari strategi ini.

Setelah ditentukan target dari pelaksanaan strategi, kemudian ditentukan bentuk program yang mengacu pada kebutuhan setiap unit perusahaan. Tidak semua bentuk program Employee Relations yang direncanakan sesuai dengan kebutuhan karyawan. Hal ini disebabkan oleh data yang dijadikan sebagai landasan untuk 
ISSN. 2527-8673

E-ISSN. 2615-6725

merencanakan program diperoleh dari hasil survey akhir tahun yang tidak spesifik.

Adapun untuk perencanaan program masing-masing departemen, diserahkan kepada kreativitas dan kebutuhan yang tengah dihadapi oleh departemen yang terkait.

Dari hasil penelitian ini dapat diketahui bahwa dalam penentuan waktu pelaksanaan program banyak menghadapi kendala utamanya adalah koordinasi antara manager setiap departemen.

Kurangnya respon pimpinan terhadap penyelenggaraan program employee relations menunjukan adanya permasalahan pada komunikasi internal yang ada pada perusahaan, manager HRD yang mewakili staff HRD untuk menyampaikan kebutuhan karyawan dalam pengelolaan program kerapkali tidak dapat mencapai tujuan dari proses komunikasi yang dilakukan dengan pimpinan perusahaan.

Setelah rangkaian proses pemetaan situasi telah dilakukan kemudian dilakukan penyesuaian program Employee Relations dengan program human resource. Hal ini bertujuan agar semua program memiliki indikator yang sama dalam pengukuran hasil nantinya.
2) Proses Pengorganisasian Employee Relations Management di PT Kemfarm Indonesia

Proses pengorganisasian Strategi Employee Relations Management di PT Kemfarm Indonesia adalah sebagai berikut:

(1) Keberadaan lembaga pengelola Employee Relations. Pengorganisasian. Srategi dilakukan oleh departemen HRD yang berada dibawah departemen $H R$ \& Communication. (2) Aktivitas fungsi pengelolaan Employee Relations. Departemen HRD berperan sebagai fungsi PR yakni menginformasikan program pada karyawan yang menjadi target dari pelatihan.

Pada aktivitas ini terdapat beberapa kendala diantaranya saluran komunikasi yang digunakan kurang efektif serta waktu dari penyampaian informasi dengan pelaksanaan program dilakukan dalam jarak waktu yang berdekatan. Kerapkali implementasi tidak sesuai dengan perencanaan. Jika ditemukan kendala di lapangan seperti ini tidak dikomunikasikan dengan departemen terkait dan terjadi miss komunikasi antar departemen.

Program Apresiasi yang dilakukan perusahaan hanya dalam bentuk pemberian bonus bagi karyawan yang tidak cuti dan 
lembur pada setiap periode kerja. Perusahaan terus membuat target untuk peningkatan jumlah produksi yang tinggi setiap tahunnya tapi tidak diiringi dengan strategi apresiasi yang optimal bagi untuk meningkatkan motivasi kerja karyawan.

Komunikasi Tatap Muka (Employee conference). Employee conference dilakukan setiap bulan atau satu minggu sekali. Tidak ada Aktivitas fungsi pengelolaan program secara khusus. Pelaksanaan bentuk program belum sesuai dengan rencana, partisipasi karyawan masih terbilang rendah di program ini.

Pola komunikasi yang terdapat pada employee conference bersifat satu arah sehingga belum optimal untuk menyampaikan aspirasi karyawan. Family Gathering. Aktivitas fungsi pengelolaan program dibantu oleh staff dari departemen lain untuk memudahkan tahap perencanaan juga pelaksanaan acara.

\section{3) Proses Pengawasan Employee Relations Management di PT Kemfarm Indonesia}

Proses pengawasan strategi Employee Relations PT Kemfarm Indonesia adalah sebagai berikut.

(1) Databased perekaman (record) situasi. Departemen HRD membuat databased perekaman (record) situasi dalam bentuk progress report program.

(2) Monitoring dilakukan untuk mengetahui pelaksanaan dan perencanaan program sesuai atau tidak serta untuk mengetahui gambaran record situasi program. Monitoring dilakukan langsung oleh Manager HRD dan Manager lainnya yang terkait dengan program. Keterlibatan Kepala Departemen, Manager Departemen lain dan Staff dari departemen lain dalam pengawasan tidak dilakukan secara langsung pada setiap acara hanya dibeberapa program tertentu saja.

(3) Dokumentasi Program. Dokumentasi program tidak dilakukan secara khusus baik di setiap program berupa dokumentasi foto ataupun catatan yang terperinci jika mendapatkan kendala di lapangan sehingga permasalahan sering terulang di program berikutnya.

(4) Pencatatan khusus. Tidak ada pencatatan khusus dalam pengawasan program. Sehingga permasalahan yang terjadi setiap tahunnnya hampir sama. 
4) Proses Evaluasi Employee Relations Management di PT Kemfarm Indonesia

Proses evaluasi Strategi Employee Relations Management di PT Kemfarm Indonesia adalah sebagai berikut.

(1) Proses evaluasi menghasilkan alternatif perbaikan Employee Relations. Proses pertama adalah menentukan tolok ukur kesuksesan. Tolok ukur kesuksesan dilihat dari tujuan awal yang ditentukan, partisipasi karyawan pada setiap program minimal $80 \%$, output yang dihasilkan dari program dan intensitas penyelenggaraan program yang sesuai dengan timeline

(2) Menentukan metode evaluasi. Dalam melakukan evaluasi, pengelola strategi Employee Relations management tidak melakukan evaluasi secara spesifik pada setiap program dan tidak ada saluran komunikasi yang dapat menyampaikan saran serta kritik karyawan.

\section{5) Proses Pengembangan Employee Relations Management di PT Kemfarm Indonesia}

Proses pengembangan strategi Employee Relations management di PT Kemfarm Indonesia adalah sebagai berikut.

1. Tingkat kualitas Employee Relations. Pengembangan kualitas program
Employee Relations bersumber dari hasil evaluasi yang dilakukan melalui survey akhir tahun dan evaluasi internal departemen dilakukan secara tidak spesifik dan tidak bisa mengukur secara pasti kebutuhan karyawan dan keinginan perusahaan untuk mengembangkan strategi yang dilaksanakan di tahun berikutnya. Tidak ada data atau presentase mengenai peningkatan produktivitas karyawan atau meningkatnya rasa nyaman karyawan di lingkungan kerja. Partisipasi karyawan terlibang masih rendah dan belum sesuai dengan target.

2. Inovasi Strategi. Selama ini tidak ada inovasi strategi Employee Relations baik dari bentuk program, ataupun waktu pelaksanaan program. Hal ini disebabkan keterbatasan fasilitas perusahaan dan kurangnya motivasi dari pimpinan perusahaan.

3. Partisipasi Pimpinan. Seluruh tahapan Strategi Employee Relations dilakukan oleh Manager Departemen dengan dibantu staff serta Manager Departemen lainnya yang terkait dengan penyelenggaraan Strategi. Untuk kepala Departemen dan Direktur mengawasi dengan memantau laporan program dan 
Commed : Jurnal Komunikasi dan Media Vol. 2 No2 Februari 2018

ISSN. 2527-8673

E-ISSN. 2615-6725

memberikan persetujuan atas penyelenggaraan program.

\section{Pembahasan}

1) Proses Perencanaan Employee Relations Management di PT

\section{Kemfarm Indonesia}

Pada proses perencanaan terdapat tahap yang belum sesuai yakni pemetaan situasi karena saluran komunikasi yang dijadikan sumber data dalam melakukan perencanaan strategi tidak spesifik.

Data hanya diperoleh melalui hasil survey tahunan yang diselenggarakan setiap satu tahun di akhir periode perusahaan. Survey dilakukan secara menyeluruh terhadap berbagai aspek lainnya di perusahaan, tidak terfokus pada strategi Employee Relations.

Selain itu, data yang bersifat satu arah tidak dapat mendeskripsikan kebutuhan karyawan secara real time atau sesuai dengan kondisi karyawan saat ini. Sehingga hasilnya tidak bisa menjadi tolok ukur yang spesifik terhadap strategi yang sudah dilaksanakan ataupun menjadi patokan untuk perencanaan strategi ditahun selanjutnya.

Dampak dari kurang spesifiknya data yang digunakan sebagai acuan pemetaan situasi terlihat dari permasalahan yang muncul pada perusahaan hampir sama setiap tahunnya. Tidak ada perbaikan atau peningkatan secara signifikan melalui strategi yang dilakukan.

Padahal dalam melakukan pemetaan situasi diperlukan data dari berbagai saluran komunikasi untuk mengetahui situasi perusahaan saat ini. Pemetaan situasi penting dilakukan karena untuk menentukan titik fokus dan aspek-aspek perusahaan yang perlu ditingkatkan atau mengidentifikasi permasalahan yang harus diselesaikan.

Kemudian dalam proses pemetaan situasi tidak dilakukan proses komunikasi secara efektif. Hasil dari pemetaan situasi perusahaan dibahas pada rapat koordinasi tahunan yang diikuti oleh seluruh manajer dari berbagai departemen.

Perusahaan sebaiknya lebih mengoptimalkan pemetaan situasi pada proses perencanaan strategi Employee Relations dengan cara melakukan pemetaan situasi secara detail dan menggunakan saluran komunikasi yang efektif. Saluran komunikasi yang digunakan sebaiknya bersifat dua arah agar kebutuhan karyawan sesuai dengan perencanaan. Termasuk proses komunikasi yang berlangsung pada 
saat pemetaan situasi sebaiknya dilakukan secara efektif.

Seperti yang dijabarkan pada penelitian yang dilakukan oleh (Lestari, 2012:120) pada proses perencanaan program Employee Relations saluran komunikasi yang digunakan tidak hanya melalui satu saluran dalam mengumpulkan data. Sehingga pada hasilnya pemetaan situasi yang dilakukan dapat menganalisis wilayahwilayah yang membutuhkan solusi atau penyelesaian.

“...saluran komunikasi selain employee survey adalah dengan komunikasi tatap muka secara langsung, kotak saran, melalui konferensi staff, dan ada juga masukan yang dapat karyawan sampaikan melalui saluran online yakni email karyawan yang dikelola oleh perusahaan..."

Pemetaan situasi sebaiknya diperoleh dari data spesifik sehingga diketahui situasi apa yang sedang dihadapi perusahaan, latar belakang apa yang menyebabkan situasi tersebut terjadi dan mengetahui seberapa penting situasi yang dihadapi tersebut mempengaruhi perusahaan. Hal ini dilakukan agar program yang direncanakan sesuai dengan kebutuhan karyawan dan situasi perusahaan. Smith (2005: 19) menjelaskan bahwa :
"Pemetaan situasi perlu mengetahui situasi apa yang sedang dihadapi perusahaan, latar belakang apa yang menyebabkan situasi tersebut terjadi (dengan mencari penyebab serta faktafakta yang ditemukan yang berkaitan dengan organisasi maupun kelompok lain) dan mengetahui seberapa penting situasi yang dihadapi tersebut mempengaruhi perusahaan (mengetahui seberapa pengaruh situasi tersebut dalam jangka waktu yang relatif singkat atau lama serta melihat peluang dari situasi tersebut)."

Kendala lain yang ditemukan pada proses perencanaan adalah komunikasi antara satu divisi dengan divisi lain dalam penentuan waktu pelaksanaan kegiatan. Juga kurangnya kesadaran bersama untuk memprioritaskan kegiatan Employee Relations.

Pimpinan perusahaan yang mengikuti rapat koordinasi sebaiknya dapat menerapkan prinsip sensing (menanggapi), evaluating dan responding agar hasil rapat dapat menghasilkan kebijakan yang sesuai dengan kebutuhan karyawan juga menyesuaikan dengan keadaan perusahaan. Proses komunikasi efektif menurut Ruslan dalam (Muhyi, dkk, 2016 : 126) adalah :

“...komponen menjadi komunikator dalam komunikasi efektif adalah be $a$ descriptive communicator, empathy, send the message clearly, communicate in the appropriate time... komponen menjadi komunikan adalah sensing 
(menanggapi), evaluating, dan responding)..."

\section{2) Proses Pengorganisasian Employee}

Relations Management di PT

\section{Kemfarm Indonesia}

Aktivitas fungsi pengelolaan

program pelatihan belum sesuai karena aktivitas pengelolaan program belum memenuhi tujuan. Hal ini dapat dilihat dari belum efektifnya saluran komunikasi yang digunakan dalam menginformasikan program pada karyawan, HRD tidak melakukan komunikasi secara personal dalam menyampaikan pesan. Selain itu sering terjadi miss komunikasi dalam pelaksanaan program. Padahal tujuan dari program pelatihan adalah menciptakan komunikasi efektif antar karyawan dan meningkatkan produktivitas karyawan. Sehingga permasalahan tersebut dapat menjadi penghambat dalam pencapaian tujuan program.

Sebaiknya pengelola program dapat menginformasikan program lebih optimal dengan cara menggunakan saluran komunikasi personal untuk menginformasikan program pelatihan. Karena saluran komunikasi personal baik yang bersifat langsung melalui perseorangan atau melalui kelompok, lebih persuasif dibandingkan dengan saluran media massa. Sehingga partisipasi program akan meningkat jika menggunakan saluran komunikasi personal. Menurut (Effendi, 2009: 212):

"...saluran komunikasi personal lebih efektif untuk menyampaikan pesan pada perseorangan. hal ini karena disebabkan faktor sebagai berikut: (1) Penyampaian pesan melalui saluran komunikasi personal dapat dilakukan secara langsung kepada khalayak yang dituju, bersifat manusiawi dan pribadi. (2) Penyampaian pesan melalui saluran komunikasi personal dapat dilakukan lebih terperinci dan lebih fleksibel disesuaikan dengan situasi dan kondisi nyata. (3) Keterlibatan khalayak dalam proses komunikasi cukup tinggi..."

Selain itu, dalam penelitian yang dilakukan oleh (Darjono, 2015) sebaiknya pengelola mensosialisasikan program secara khusus dan melalui email atau komunikasi interpersonal pada karyawan karena program pelatihan diikuti oleh karyawan berdasarkan syarat dan kebutuhan tertentu.

Aktivitas fungsi pengelolaan yang diterapkan pada program apresiasi belum sesuai. Hal ini dikerenakan aktivitas fungsi pengelolaan tidak dilakukan secara khusus dan tujuan pelaksanaan program belum sesuai dengan kebutuhan karyawan. Padahal setiap program harus sesuai dengan tujuan dan dapat memenuhi kebutuhan karyawan. 
Sebaiknya perusahaan dapat mengelola program dengan lebih optimal dengan cara membuat program penghargaan selain penghargaan finansial bagi karyawan. Dalam penelitian yang dilakukan oleh (Lestari, 2012: 112-113) menjelaskan bahwa program penghargaan akan efektif jika dilakukan sesuai dengan kebutuhan karyawan.

Program apresiasi sebaiknya dilakukan tidak hanya berupa apresiasi finansial, juga dilakukan dalam bentuk apresiasi informal berupa email dari pimpinan, thank you note, dan apresiasi internal. Sehingga pengelolaan program dapat sesuai dengan tujuan strategi Employee Relations.

Program employee conference dapat dilakukan lebih optimal dengan cara menerapkan komunikasi dua arah agar dapat mencapai tujuan program. Melalui komunikasi dua arah maka segala macam saran dapat tersampaikan baik dari karyawan ke manajemen maupun sebaiknya. Pada akhirnya akan berdampak positif bagi peningkatan kinerja karyawan. Menurut (Effendy, 2009 : 214-215) :

"Komunikasi vertikal yakni komunikasi dari atas ke bawah (downward communication) dan dari bawah ke atas (upward communication), adalah komunikasi dari pimpinan kepada bawahan dan dari bawahan kepada pimpinan secara timbal balik (two-way traffic communication). Komunikasi dua arah secara timbal balik tersebut dalam organisasi penting sekali karena jika hanya satu arah saja dari pimpinan kepada bawahan, laporan, tanggapan, atau saran para karyawan sehingga suatu keputusan atau kebijaksanaan dapat diambil dalam rangka mencapai tujuan yang telah ditetapkan."

\section{3) Proses Pengawasan Employee \\ Relations Management di PT}

\section{Kemfarm Indonesia}

Sebaiknya perekaman situasi program dilakukan lebih optimal dengan cara membuat progress report yang ditulis setiap harinya secara spesifik dalam pelaksanan program dan dibahas dalam rapat khusus. Sehingga dapat diketahui kemajuan persiapan setiap program. Agar pengelola dapat mengetahui sejauh apa efek yang ditimbulkan, apa saja yang kurang, dan apa saja yang perlu dibenahi. (Atkin \& Rice, 2001: 106) menyatakan:

"Evaluasi kedua yaitu saat implementasi disebut dengan process research, yaitu monitoring yang mencakup aktivitasaktivitas untuk mengetahui pelaksanaan/implementasi di lapangan, mengetahui apakah program ditangkap oleh audiens yang sesuai dengan rencana."

Sebaiknya perusahaan melakukan dokumentasi dan pencatatan untuk setiap 
kasus yang ada pada saat pelaksanaan setiap program secara detail, agar permasalahan yang terdapat pada pelaksanaan program tidak terulang pada tahun berikutnya. Stecker \& Linnan dalam (Atkin \& Rice, 2001: 106) bahwa : "Dengan adanya proses evaluasi dalam bentuk dokumentasi yang terperinci dapat mengetahui program yang dapat diperbaiki untuk desainer dan orang yang melanjutkan kedepannya."

\section{4) Proses Evaluasi Employee Relations Management di PT Kemfarm Indonesia}

Sebaiknya proses evaluasi setiap program dilakukan lebih optimal dengan cara melakukan serangkaian proses evaluasi secara detail di setiap program dan menggunakan data yang tepat dan berkesinambungan dengan proses sebelumnya yakni monitoring. Adapun proses evaluasi menurut (Akdon, 2011:179) adalah : “(1) Analisis logika program. (2) Desain evaluasi. (3) Penyusunan desain evaluasi serta strategi pengumpulan dan analisis data."

Sehingga hasil evaluasi dapat menjadi tolok ukur untuk melihat keberhasilan program agar dapat dijadikan sumber data pengembangan strategi Employee Relations kedepannya.
Penelitian sebelumnya yang dilakukan oleh (Darjono, 2015) memberikan rekomendasi bahwa perusahaan perlu membuat suatu bentuk evaluasi yang khusus dan sederhana untuk setiap kegiatan dalam program Employee Relations, dan dilakukan secara rutin agar dapat menilai keberhasilan program secara efektif. Berikut adalah kutipan hasil penelitian tersebut.

“... sebaiknya perusahaan membuat evaluasi khusus pada setiap program Employee Relations. Dengan ini perusahaan dapat menilai mana program-program yang dapat dinilai efektif bagi Employee Relations. Dari hasil evaluasi tersebut, perusahaan dapat memilah mana program yang perlu tetap dilanjutkan dan mana yang harus diganti."

Selain itu, saran yang dijelaskan dalam penelitian (Darjono, 2015) adalah dengan merancang media komunikasi internal untuk menyebarkan informasi perusahaan. Hal tersebut dapat diterapakan pada metode evaluasi di PT Kemfarm Indonesia yang selama ini belum memiliki media komunikasi internal yang dapat menjadi sarana untuk menyebarkan informasi dan saluran untuk menyampaikan aspirasi karyawan pada perusahaan. 


\section{5) Proses Pengembangan Employee Relations Management di PT Kemfarm Indonesia}

Sebaiknya proses pengembangan strategi Employee Relations dilakukan lebih optimal dengan cara melakukan pengembangan program melalui data yang spesifik melakukan presentase keberhasilan setiap program yang sesuai dengan indikator dari setiap program yang diselenggarakan. Sehingga dapat mendukung pengembangan program kedepannya agar program dapat dikembangan pada tahun berikutnya.

Dalam pelaksanaan program tidak dilakukan inovasi. Strategi Employee Relations baik dari bentuk program, ataupun waktu pelaksanaan strategi. Hal ini disebabkan keterbatasan fasilitas perusahaan dan kurangnya motivasi dari pimpinan perusahaan. Sebaiknya pimpinan perusahaan melakukan motivasi pada karyawan. Sebab, menurut (Mahavidyalaya, 2015) dalam penelitiannya menjelaskan motivasi penting dalam meningkatkan kepuasan karyawan, yang nantinya akan menghasilkan inovasi pada setiap program yang dikerjakan.

Adapun motivasi dapat dilakukan melalui komunikasi interpersonal secara rutin, pelatihan, menyediakan kesempatan bagi karyawan untuk berkembang, dan lingkungan kerja yang nyaman. Berikut adalah kutipan hasil penelitian tersebut.

“...motivation is important process to collect proper work and job satisfaction of employee. Library can motivate their employee by Training, Orientation, Fairness at work place, providing opportunities, regular appraisal, regular communication, reward..."

Partisipasi pimpinan dari seluruh tahapan strategi Employee Relations dilakukan oleh Manager Departemen dengan dibantu staff serta Manager Departemen lainnya yang terkait dengan penyelenggaraan strategi. Untuk kepala Departemen dan Direktur mengawasi dengan memantau laporan program dan memberikan persetujuan atas penyelenggaraan program. Hal ini sudah sesuai, karena dari tahap pengelolaan strategi Employee Relations perusahaan sudah menunjuk manager HRD untuk bertanggungjawab atas penyelenggaraan strategi Employee Relations.

\section{KESIMPULAN DAN SARAN}

\section{Kesimpulan}

1. Proses Pengawasan Employee Relations Management di PT Kemfarm Indonesia Proses Perencanaan Strategi Employee Relations Management di PT Kemfarm Indonesia meliputi penetapan 
tujuan strategi, melakukan pemetaan situasi dan sinergi perencanaan program Employee Relations dan HR. Semua tahap sudah dilaksanakan sesuai dengan unsur-unsur perencanaan pada umumnya. Namun pemetaan situasi tidak dilakukan secara spesifik, data yang diperoleh tidak berasal dari saluran komunikasi yang beragam, dan belum dilakukan komunikasi yang efektif dalam menentukan perencanaan waktu pelaksanaan kegiatan.

2. Proses Pengorganisasian Employee Relations Management di PT Kemfarm Indonesia

Proses Pengorganisasian Strategi Employee Relations Management di PT Kemfarm Indonesia, meliputi keberadaan lembaga pengelola Employee Relations dan aktivitas fungsi pengelolaan Employee Relations, yang terdiri dari Program Training, Program apresiasi, Komunikasi Tatap Muka (Employee conference), dan Family Gathering. Pengorganisasian program dilakukan oleh departemen HRD yang berada dibawah departemen $H R$ \& Communication. Namun pada tahap aktivitas fungsi pengelolaan Employee Relations belum sesuai. Pada pengorganisasian program pelatihan saluran komunikasi yang digunakan belum optimal dan pola komunikasi yang diterapkan pada pelaksanaan program tidak sesuai dengan kebutuhan karyawan.

3. Proses Pengorganisasian Employee Relations Management di PT Kemfarm Indonesia

Proses pengawasan strategi Employee Relations Management di PT Kemfarm Indonesia meliputi membuat databased perekaman (record) situasi dengan menunjuk Manager HRD yang bertanggungjawab sebagai pengawas program, membahas record situasi program, dan monitoring secara langsung. Tahap kedua adalah dokumentasi program. Tahap ketiga adalah pencatatan khusus.

4. Proses Pengorganisasian Employee Relations Management di PT Kemfarm Indonesia

Proses evaluasi strategi Employee Relations management di PT Kemfarm Indonesia meliputi proses evaluasi menghasilkan alternatif perbaikan Employee Relations. Pada tahap menentukan metode evaluasi belum sesuai karena metode evaluasi yang digunakan adalah survey akhir tahun yang tidak spesifik dan tidak ada saluran komunikasi untuk mengevaluasi program. Kemudian tingkat rutinitas evaluasi program pun masih belum sesuai 
ISSN. 2527-8673

E-ISSN. 2615-6725

karena dilakukan setiap satu bulan sekali yang dibahas pada rapat internal divisi.

5. Proses Pengorganisasian Employee

Relations Management di PT

Kemfarm Indonesia

Proses pengembangan strategi

Employee Relations management di PT

Kemfarm Indonesia meliputi tingkat kualitas

Employee Relations, inovasi strategi dan

artisipasi pimpinan. Secara keseluruan

program Employee Relations belum

berkembang setiap tahunnya. Dapat diketahui dari tahap tingkat kualitas Employee Relations yang belum optimal.

\section{Saran}

1. Perusahaan sebaiknya lebih mengoptimalkan proses pemetaan situasi pada perencanaan strategi dengan cara membuat pemetaan situasi secara detail.

2. Sebaiknya dalam proses perencanaan program, pengelola melakukan komunikasi secara transparan yakni dengan mengesampingkan hirarki atau tingkatan jabatan pada saat menyampaikan pesan.

3. Sebaiknya dalam proses aktivitas pengelolaan program pelatihan, perusahaan dapat menginformasikan program lebih optimal dengan cara menggunakan saluran komunikasi personal untuk menginformasikan program pelatihan.

4. Sebaiknya aktivitas fungsi pengelolaan program yang diterapkan pada program employee conference dilakukan secara terperinci dan melibatkan seluruh karyawan dan melakukan komunikasi dua arah pada saat pelaksanaannya.

5. Sebaiknya perekaman situasi program dilakukan dengan cara membuat progress report yang ditulis setiap harinya secara spesifik dalam pelaksanan program dan dibahas dalam rapat khusus.

6. Sebaiknya proses evaluasi setiap program dilakukan melalui serangkaian proses evaluasi secara detail di setiap program dan menggunakan data yang tepat dan berkesinambungan dengan proses sebelumnya yakni monitoring.

7. Sebaiknya perusahaan melakukan pengembangan program melalui data yang spesifik dan melakukan presentase keberhasilan setiap program yang sesuai dengan indikator dari setiap program yang diselenggarakan.

8. Penelitian ini mendeskripsikan proses employee relations management secara umum. Sebaiknya pada penelitian 
selanjutnya penelitian fokus membahas mengenai strategi komunikasi pada employee relations di sebuah perusahaan agar sesuai dengan bidang ilmu public relations.

\section{DAFTAR PUSTAKA}

Akdon, (2011). Strategic Management For Educational Management (Manajemen Strategik untuk Manajemen Pendidikan). Bandung: Alfabeta.

Atkin, C.K. dan Rice, R.E. (2001). Public Communication Campaign. 3rd Edition. London: Sage Publication, Inc.

Darjono, Felisia Yosicho. (2015). Evaluasi Program Employee Relations Toyota Asri Motor Tahun 2015. Surabaya: Universitas Kristen Petra.

Effendi, Onong Uchjana. (2003). Ilmu, Teori Dan Filsafat Komunikasi. Bandung: Citra Aditya Bakti.

Hasibuan, Malayu S.P, 2006. Manajemen Dasar, Pengertian, dan Masalah,Edisi Revisi. Bumi Aksara:Jakarta

Jefkins, Frank dan Yadin. 2003. Public Relations Edisi Revisi Kelima. Jakarta: Erlangga.

Lestari, Yeni, Indah. (2012). Perapan Employee Relations dalam Iklim Komunikasi Internal. Jakarta: Universitas Indonesia.

Mahavidyalaya, Matsyodari. 2015. Employee relationship Management
To Improve Efficiency Of Library Staff. 02 : 05-17.

Muhyi, Muttaqin \& Nirmalasari. (2016). HR Plan \& Strategy (Strategi Jitu Pengembangan Sumber Daya Manusia. Jakarta: Penebar Swadaya Group.

Nassaluka, E. U. R., Hafiar, H., \& Priyatna, C. C. (2016). Model Kemitraan PT. Holcim Indonesia Tbk. Jurnal Profesi Humas, 1(1), 22-34.

Nazir, Moh. (2003). Metode Penelitian. Jakarta; Ghalia Indonesia.

Rakhmawati, R., \& Sani, A. (2016). Implementasi Kegiatan Corporate Communication Oleh Divisi Corporate Secretary Pt. Bio Farma (Persero). Jurnal Profesi Humas, 1(1), 40-52.

Ruslan, Rosadi. 2007. Manajemen Public Relations. Jakarta: PT Raja Grafindo Persada.

Smith, D. Ronald. (2005). Strategic Planning For Public Relations, Second Edition. London: Lawrence Erlbaum Associates Publisher.

Suparna, P., Rahmawati, T. S., \& Winoto, Y. (2013). Keterbukaan Komunikasi dalam Menciptakan Iklim Komunikasi yang Kondusif di Perpustakaan. Jurnal Kajian Informasi \& Perpustakaan, 1(2), 157-164.

https://www.slideshare.net/indopacedelma n/2012-edelman-trust-barometer indonesian-findings, (diakses pada 05 Februari 2017 